\title{
ANGIOGENESIS IN ADVANCED COLORECTAL ADENOCARCINOMA WITH SPECIAL REFERENCE TO TUMORAL INVASION
}

\author{
Cláudio TARTA ${ }^{1}$, Cláudio Rolim TEIXEIRA ${ }^{1}$, Shinji TANAKA ${ }^{2}$, \\ Ken HARUMA ${ }^{2}$, César CHIELE-NETO ${ }^{1}$ e Vinícius Duval da SILVA ${ }^{1}$
}

\begin{abstract}
Background - Angiogenesis is a crucial step in tumor growth and progression. Its quantification by microvessel counting has a prognostic value in several types of malignancies and recently has been appraised in gastrointestinal tumors. Aim - To assess the prognostisc significance of microvessel quantification in colorectal carcinomas, studying its association with hematogenous metastases, survival and clinicopathological variables such as size, histologic differentiation and depth of tumoral invasion. Patients/Methods - Forty eight patients with colorectal adenocarcinoma were included in this study. Histologic sections of invasion tumoral margin $(4 \mu \mathrm{m})$ were analyzed and endothellined microvessels were immunostained with monoclonal mouse Von Willebrand Factor (anti-FVIII). The microvessel count was performed from the identification of the area with increased microvessel density - hot spots - and results of the mean in five of these fields. Results - The cut-off microvessel count was 14 microvessels $/ 0,785 \mathrm{~mm}^{2}$, which divided the sample into hypovascular and hypervascular groups. While $2 / 8(25 \%)$ tumors with muscularis propria invasion were classified as hypervascular, 11/15 (73\%) tumors with serosa or perivisceral fat were classified as hypervascular. However, a non-significant statistical association was found between the angiogenesis quantification, hematogenous metastases, survival and clinicopathological variables such as size and histologic differentiation of the tumor. Conclusions - The findings of significantly increase of microvessel count in conformity with tumoral invasion depth supports the hypothesis that tumor progression might be related to angiogenesis. Although angiogenesis is an important step in the tumoral growth and during the metastatization process, other factors can be implicated.
\end{abstract}

HEADINGS - Colorectal neoplasms. Adenocarcinoma. Neovascularization, pathologic.

\section{INTRODUCTION}

In the study of colorectal carcinoma, one of the most prevalent solid tumors, risk factors as well as the most commonly used clinicopathological staging systems have been investigated. Among them, the quantification of tumor angiogenesis and angiogenic peptides have had clinical application in the assessment of recurrence and survival ${ }^{(6)}$.
Since FOLKMAN ${ }^{(8)}$ showed that tumor growth is dependent on angiogenesis when he isolated the tumor angiogenesis factor, the role of angiogenesis in the growth of primary and the metastatic tumor and its association with hematogenous metastases and survival have been extensively studied. In breast cancer, for example, most published studies have shown a statistically significant correlation between neovascularization and worse prognosis $^{(2,13,14,21,32,33)}$. Microvascularization has been assessed

Department of Surgery and Pathology, Federal University of Rio Grande do Sul, Porto Alegre, RS, Brazil. ${ }^{2}$ First Departament of Internal Medicine, Division of Gastroenterology, Hiroshima University School of Medicine, Hiroshima, Japan.

Address for correspondence: Dr. Cláudio Tarta - Rua Mostardeiro, 157/403 - 90430-001 - Porto Alegre, RS, Brazil. e-mail: tarta.ez@ terra.com.br 
in lung, urinary and gastrointestinal tumors, demonstrating the prognostic importance of angiogenesis, that is, the significant association between high tumor vascularization and shorter survival, an increase in the risk of recurrence and hematogenous metastasis ${ }^{(4,6,18,34,35)}$. However, there have been few studies on the prospective relationship between prognosis and the increment of tumor microvessels. The role of angiogenesis in colorectal carcinoma studying the association between neovascularization and prognosis has been recently published ${ }^{(7,30,31)}$.

This study will focus on angiogenesis in advanced colorectal adenocarcinoma and its association with depth of tumor invasion, hematogenous metastasis and patient survival.

\section{MATERIAL AND METHODS}

Paraffin-embedded tumor especimens from 48 patients with advanced colorectal adenocarcinoma, selected at random (draw) from 292 patients, who had undergone surgery at the Hiroshima University School of Medicine, Hiroshima, Japan, from 1988 to 1991. This period was chosen to be assured of adequate follow-up. Patients who received any form of adjuvant chemoterapy, had a familial cancer syndrome, or had another concurrent malignant neoplasm were excluded from further analysis. The pathology reports and clinical records were reviewed to determine disease stage and recurrence, including colonoscopy, image methods and CEA dosage. In addition, all pathologic slides were reviewed without knowledge of previous pathologic findings or patient outcome to carefuly determine staging.

Out of the 48 patients in the sample, $32(66,7 \%)$ were male and 16 $(33,3 \%)$ were female. Mean patient age was 65 years old and standard deviation was 10,4. As to tumor site, $27(56,2 \%)$ were located at rectal and rectosigmoid junction. Most tumors were resected by anterior retossigmoidectomy and abdominoperineal resection. Mean follow-up found in patients was 1,197 days (range: 34-1953). According to the histologic features at the deepest level of tumor invasion (the tumor apex), the tumors were classified as follows: well differentiated (W), moderately differentiated (M), and poorly differentiated $(\mathrm{P})$. By assessing its glandular configuration and cellular arrangement, the $\mathrm{M}$ type was further subdivided in two different groups: moderately well differentiated $(\mathrm{Mw})$ and moderately poorly differentiated $(\mathrm{Mp})$ carcinomas $^{(27)}$.

\section{Immunohistochemistry}

Endothelial cells were analyzed by immunostaining tissue sections of invasive tumour margin. A specific endothelial antibody, the monoclonal mouse, anti-FVIII - Von Willebrand Factor (DAKO-vWf, F8/86, Dako, Denmark) - and DAKO StrepABComplex/HRP Duet, mouse/rabbit (DAKO A/S) were used as primary and secondary antibodies, and DAKO DAB was the chromogen tablet used. The tissue section analysis showed brown immunoreactivity (DAB) contrasting with a blue background
(Mayer hematoxilin). Microvessels were counted according to the methodology presented by VERMEULEN et al. ${ }^{(30)}$. Each tissue section was analyzed at $\mathrm{x} 100$ in order to pinpoint the areas with intense vascularization - the hot spots - which presented the highest density of brownish coloration (anti-FVIII antibody) (Figure 1). Microvessel count was set in an ordinal scale calculated by the mean of the highest number of microvessels found within five densely vascularized fields at x160, corresponding to an area of $0,785 \mathrm{~mm}^{2}$.

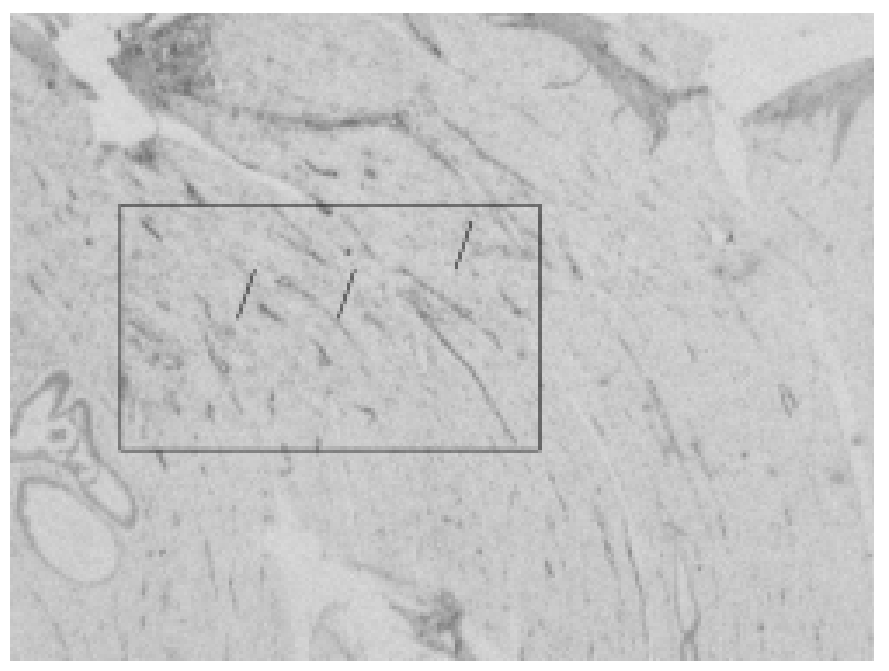

FIGURE 1 - Invasive tumour margin. Microscopic finding of microvessels stained (arrows-brown immunoreactivity) contrasting with a blue background (Mayer hematoxilin). Inset: hot spot.

\section{Statistical Analysis}

The correlation between tumor size (y) and microvessel counting (x) was assessed by calculating the Pearson coefficient (r), and its significance was calculated by using the $t$ Student test. The latter was also used to compare the means of tumor size across hyper- and hypovascularized groups for independent samples. After that, the survival analysis was carried out through the Kaplan-Meier technique, and the groups were compared by using the log-rank test. The significance level adopted in this study was $P=0.05$.

\section{RESULTS}

\section{Microvessel count and histopathological variables}

Microvessel counts (mean \pm standard deviation) was $15 \pm 6,87$ microvessels/field (median: 14; range: 5,8-32,4). The sample was later divided into two groups: (a) hypervascularized group, whose microvessel counts was either the same as or superior to the median one $(\geq 14$ 
microvessels/field), and (b) hypovascularized group, which showed microvessel counts below the median one ( $<14$ microvessels/field). No significant association was found between microvessel count and age, sex, tumor size and histological differentiation (Tables 1,2$)$.

\section{Microvessel count and depth of invasion}

It was observed that deeper tumor invasion significantly increase the rate of high microvessel count in an almost linear fashion $(P=0,02)$ (Table 3).

\section{Microvessel count and hematogenous metastases}

Hematogenous metastases were found in $20(41,7 \%)$ cases; 13 $(65 \%)$ were synchronic and $7(35 \%)$ metachronic. Hepatic metastases were the most frequent ones (70\% of the cases), followed by lung ( $25 \%$ of the cases), and multiple (liver, lung and bone), which accounted for $5 \%$ of the cases. Mean microvessel count in the hematogenous metastases group (mean \pm standard deviation) was $16,5 \pm 7,9$ whilst in the group without metastases it was $14,1 \pm 6$.

TABLE 1 - Tumor size and microvessel count

\begin{tabular}{|c|c|c|c|c|}
\hline & \multicolumn{3}{|c|}{ Tumor size $(\mathbf{m m})$} & \multirow[t]{2}{*}{$\mathbf{n}$} \\
\hline & \multicolumn{3}{|c|}{ Average \pm Standard deviation } & \\
\hline Hypervascular ( $\geq 14$ microvessel) & 50,25 & \pm & 24,51 & 24 \\
\hline Hypovascular $(<14$ microvessel $)$ & 45,00 & \pm & 15,44 & 24 \\
\hline
\end{tabular}

TABLE 2 - Histological differentiation and microvessel count

\begin{tabular}{lccc}
\hline \multirow{2}{*}{ Histological differentiation } & \multicolumn{2}{c}{ Microvessel count } & Total \\
\cline { 2 - 4 } & Hypervascular & Hypovascular & \\
\hline Well & 4 & 7 & 11 \\
Moderately well & $12,4 \%$ & $63,6 \%$ & 23 \\
Moderately poor & $52,2 \%$ & 11 & 14 \\
Total & 6 & $47,8 \%$ & \\
\hline
\end{tabular}

TABLE 3 - Tumoral invasion and microvessel count

\begin{tabular}{lccc}
\hline Depth of invasion & Hypervascular & Hypovascular & Total \\
\hline Muscularis propria & 2 & 6 & 8 \\
Subserosa & $25 \%$ & $75 \%$ & \\
& 11 & 14 & 25 \\
Serosa and perivisceral fat & $44 \%$ & $56 \%$ & 15 \\
& 11 & 4 & 48 \\
Total & $73,3 \%$ & $26,7 \%$ & $(P=0.02)$
\end{tabular}




\section{Microvessel count and patient survival}

Mean follow-up found in patients was 1197 days (range: 341953). Survival in the hypo- and hypervascularized groups was compared by using the Kaplan-Meier method, and the survival rate was, respectively, 86,4 and 63,6\% $(P=0,12)$ (Figure 2).

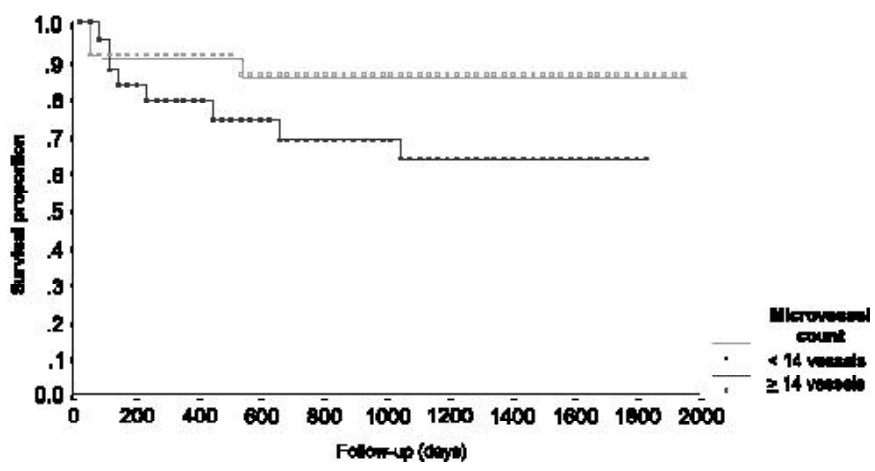

FIGURE 2 - Proportion of survival in hypo and hypervascular groups $(p=0,12)$

\section{DISCUSSION}

Although there is significant variability in the populations and in the methodology of assessment used in most published studies, they have shown the prognostic importance of angiogenesis in human solid tumors ${ }^{(9)}$. However, in order to be a reliable prognosis factor, angiogenesis quantification has to be assessed through a methodology presenting low intra and inter- observer variability, allowing for the comparison of results coming from different institutions. VERMEULEN et al. ${ }^{(30)}$ has already proposed the standardization of methodologies for angiogenesis quantification.

TEIXEIRA et al. ${ }^{(27,28)}$ have demonstrated that moderately-poorly differentiated tumors present higher malignant potential, through the higher incidence of lymphatic and venous invasion and lymphonodal and hepatic metastasis. The data in the present study show a nonsignificant statistical difference in higher microvessel density of moderately-poorly differentiated tumors. The higher tumor spreading activity observed in this histologic subgroup is supported by angiogenesis, as it has been previously demonstrated from the higher expression of the proliferating cellular nuclear antigen - PCNA. However, other factors are probably associated to the higher potential for tissue invasion and metastases in this group, such as tumor cell aggregation to vascular endothelium, the breakdown of the endothelial basement membrane and the digestion of the extracellular matrix by enzimes produced in the tumor cells.

The present study shows that colorectal carcinomas with higher angiogenesis quantification in the invasive tumor margin are associated with deeper tissue invasion. This finding is comparable to previous reports which claim that the tumor spreading activity is fueled by angiogenesis ${ }^{(20,23,26)}$. CHOI et al. ${ }^{(5)}$ found a non-significant difference between high microvessel counts and deeper tumor invasion. LIOTTA et al. ${ }^{(16)}$ have shown that both the stages - angiogenesis and tumor invasion - are functionally related. A characteristic shared by many growth factors which trigger angiogenesis, such as bFGF, is the stimulus provided by endothelial cells in three specific functions: proteolysis, motility, and spreading. Such triad of properties also characterize tumor invasion.

The tumor invasion in tissues adjacent to the primary tumor and the spreading in blood vessels are central aspects of the metastatic process. In the present investigation, a higher, but non-statistically significant microvessel density was found in patients presenting both synchronous and metachronous hematogenous metastases. The literature reports higher microvessel density in patients suffering from primary colorectal carcinoma and hematogenous metastasis ${ }^{(26,29,31)}$. However, angiogenesis quantification by itself cannot identify all the patients with hidden metastatic diseases nor even those who are likely to develop distant metastases, due to the heterogeneity of cell population and to the multiplicity of stages in the metastatic cascade which have to be accomplished by the tumor cells ${ }^{(16)}$.

By the end of the follow-up, a higher rate of survival was found in the hypovascularized group $(86,4 \%)$ in comparison with the hypervascularized one $(63,6 \%)$. Despite the $22,8 \%$ difference, no statistical significance was found $(P=0.12)$, which may be put down to the sample size. The most of studies assessing angiogenesesis in colorectal carcinoma has shown a significant association between

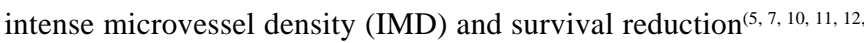
15, 20, 22, 23, 24, 25, 26, 29) (Table 4). VERMEULEN et al. ${ }^{(31)}$ carried on the first prospective study assessing angiogenesis in colorectal carcinoma, confirming the prognostic significance of microvessel counting previously demonstrated by retrospective studies. Although most studies of advanced colorectal cancer have highlighted the prognostic value of microvessel counting, there have been some controversial data $^{(3,17)}$ which can be attributed to the use of methodology that vary considerably in the microvessel counting method, originally introduced by WEIDNER et al. ${ }^{(32)}$ and recently modified by VERMEULEN et al. ${ }^{(30)}$. However, authors using this conventional microvessel counting method as BANNER et al. ${ }^{(1)}$ found higher MVD in colorectal carcinoma patients who had longer survival, but it was not statistically significant and PAVLOPOULOS et al. ${ }^{(19)}$ found prognostic significance in advanced colorectal carcinoma regarding only vascular ramifications and the total vascular area.

It is possible to state that the angiogenesis quantification, among other prognostic factors commonly used in the evaluation of colorectal carcinoma patients, can be an important indicator of the tumor biological behavior by identifying a subgroup of tumors with a higher 
Tarta C, Teixeira CR, Tanaka S, Haruma K, Chiele-Neto C, Silva VD. Angiogenesis in advanced colorectal adenocarcinoma with special reference to tumoral invasion

TABLE 4 - Summary of the results of the diferent reports on vascularisation in colorectal carcinoma

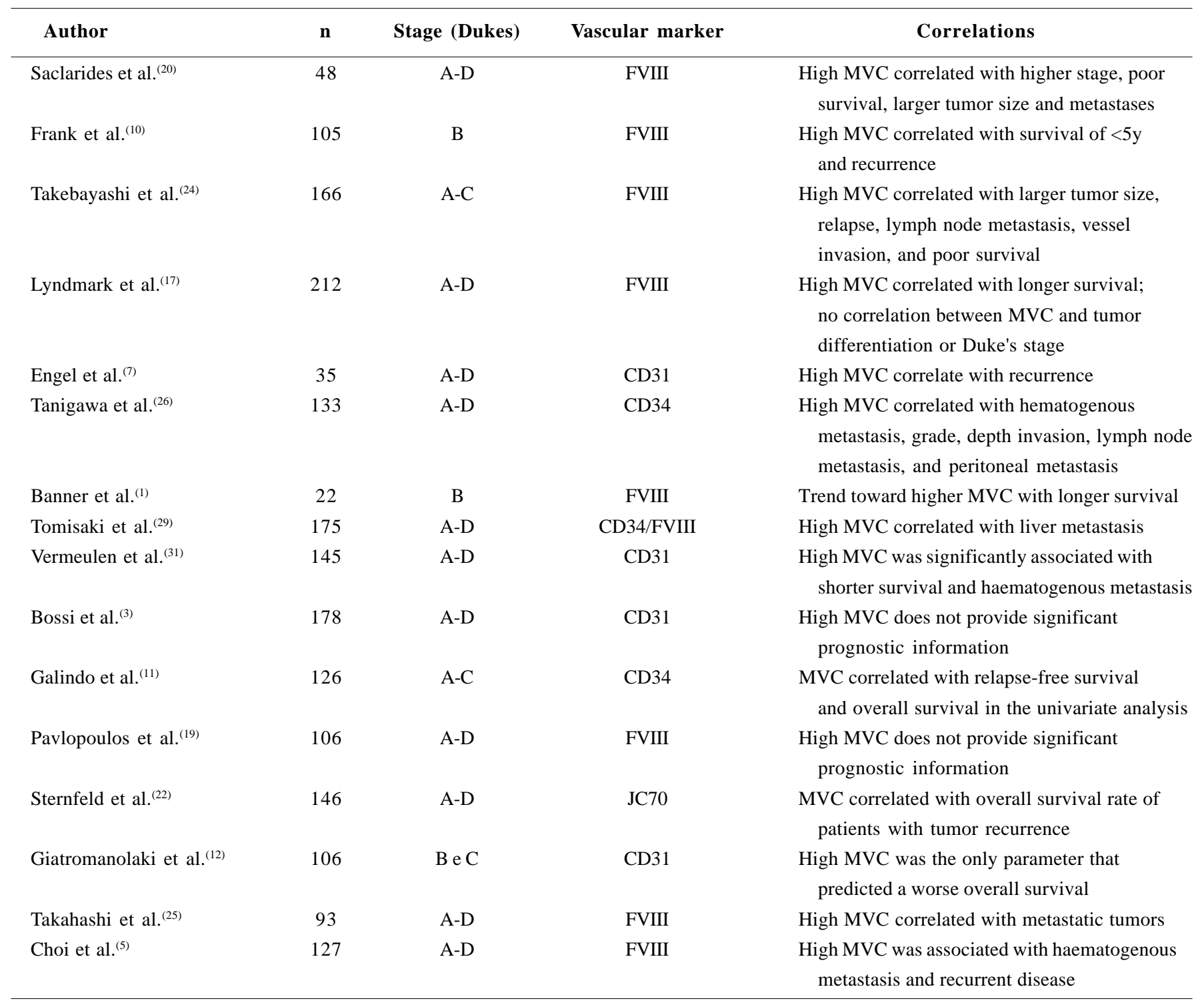

$\mathrm{MVC}=$ microvascular count

malignant potential. This was demonstrated in this limited sample by deeper tumor invasion closely associated to an increased rate of microvessel count. To establish angiogenesis as a reliable prognostic indicator it would be essential to standardize the immunohistochemical staining and microvascular quantification methods, besides providing bigger and prospective samples.

\section{ACKNOWLEDGEMENTS}

We are grateful to Dr. Pedro Gus, Director, Colorectal Surgery, Federal University of Rio Grande do Sul and Dr. João Carlos Prolla, Director, Citopathology, Federal University of Rio Grande do Sul, Porto Alegre, RS, Brasil. 
Tarta C, Teixeira CR, Tanaka S, Haruma K, Chiele-Neto C, Silva VD. Angiogênese no adenocarcinoma colorretal avançado com especial referência à invasão tumoral. Arq Gastroenterol 2002;39(1):32-8.

RESUMO - Racional - A angiogênse é uma etapa fundamental no crescimento e progressão tumoral. Sua quantificação, através da contagem microvascular, apresenta valor prognóstico em muitas neoplasias malignas e, recentemente, tem sido avaliada em tumores gastrointestinais. Objetivos - Avaliar a significância prognóstica da contagem microvascular no carcinoma colorretal, estudando sua associação com metástases hematogênicas, sobrevida e variáveis clinicopatológicas, tais como tamanho, diferenciação histológica e profundidade de invasão tumoral. Pacientes/Métodos - Foram incluídos 48 pacientes com adenocarcinoma colorretal. Secções histológicas contendo a margem tumoral invasiva $(4 \mathrm{~mm})$ foram analisadas e os microvasos foram identificados através de imunohistoquímica utilizando o anticorpo monoclonal anti-FVIII (Von Willebrand Factor - mouse). A contagem microvascular foi realizada através da identificação de áreas com maior densidade microvascular - hot spots - e resulta da média entre cinco destas áreas. Resultados - A contagem microvascular mediana foi de 14 microvasos $/ 0,785 \mathrm{~mm}^{2}$, dividindo a amostra em grupos hipo e hipervascular. Enquanto 2/8 (25\%) tumores com invasão da muscular própria foram classificados como hipervasculares, $11 / 15(73 \%)$ tumores com invasão da serosa ou tecidos peri-colônicos foram classificados como hipervasculares. No entanto, associação não significativa foi encontrada entre a quantificação angiogênica e metástases hematogênicas, sobrevida e variáveis clinicopatológicas, tais como o tamanho tumoral e diferenciação histológica. Conclusões - O achado de aumento significativo na contagem microvascular em conformidade com a maior profundidade de invasão tumoral suporta a teoria que a progressão tumoral possa estar relacionada à angiogênese. Embora a angiogênese seja etapa importante no crescimento tumoral e durante a metastatização à distância, outros fatores podem estar implicados em tais processos.

DESCRITORES - Neoplasias colorretais. Adenocarcinoma. Neovascularização patológica.

\section{REFERENCES}

1. Banner BF, Whitehouse R, Baker SP, Swanson RS. Tumor angiogenesis in stage II colorectal carcinoma - association with survival. Am J Clin Pathol 1998; 109:733.

2. Bosari S, Lee AKC, Delellis RA, Heatley G, Wiley B, Silverman ML. Microvessel quantitation and prognosis in invasive breast carcinoma. Hum Pathol 1992;23:755.

3. Bossi P, Giuseppe V, Lee AKC, Alfano RM, Coggi G, Bosari S. Angiogenesis in colorectal tumors: microvessel quantitation in adenomas and carcinomas with clinicopathological correlations. Cancer Res 1995;55:5049-53.

4. Bremer GL, Tiebosch AT, van der Putten HW, Schouten HJ, de Haan J, Arends JW. Tumor angiogenesis: an independent prognostic parameter in cervical cancer. Am J Obstet Gynecol 1996;174:126.

5. Choi HJ, Hyun MS, Jung GJ, Kim SS, Hong SH. Tumor angiogenesis as a prognostic predictor in colorectal carcinoma with special reference to mode of metastasis and recurrence. Oncology 1998;55:575.

6. Chung YS, Maeda K, Sowa M. Prognostic value of angiogenesis in gastrointestinal tumors. Eur J Cancer 1996;32:2501.

7. Engel CJ, Bennett ST, Chambers AF, Doig GS, Kerkvliet N, O'malley FP. Tumor angiogenesis predicts recurrence in invasive colorectal cancer when controlled for Dukes staging. Am J Surg Pathol 1996;20:1260.

8. Folkman J. Tumor angiogenesis: therapeutic implications. N Engl J Med 1971;285:1182.

9. Folkman J. Clinical applications of research on angiogenesis. N Engl J Med 1995;333:1757

10. Frank RE, Saclarides TJ, Leurgans S, Speziale NJ, Drab E, Rubin DB. Tumor angiogenesis as a predictor of recurrence and survival in patients with nodenegative colon cancer. Ann Surg 1995;222:695.

11. Galindo GM, Fernandez AMJ, Sanz OJ, Aljama A. Vascular enumeration as a prognosticator for colorectal carcinoma. Eur J Cancer 2000;36:55.

12. Giatromanolaki A, Stathopoulos GP, Tsiobanou E, Papadimitriou C, Georgoulias V, Gatter KC, Harris AL, Koukourakis MI. Combined role of tumor angiogenesis, bcl-2, and p53 expression in the prognosis of patients with colorectal carcinoma. Cancer 1999;86:1421.

13. Horak E, Leek R, Klenk N, Lejeune S, Smith K, Stuart N, Greenall M, Sptepniewska $\mathrm{K}$, Harris A. Angiogenesis, assessed by platelet/endothelial cell adhesion molecule antibodies, as indicator of node metastases and survival breast cancer. Lancet 1992;340:1120.
14. Kaldjian E, Jin L, Lloyd R. Immunohistochemical analysis of breast carcinomas: correlation of estrogen and progesterone receptors, proliferative activity, tumor vascularity and lymph node metastasis. Mod Pathol 1992;5:14.

15. Kimura T, Tanaka S, Haruma K, Sumii K, Kajiyama G, Shimamoto F, Kohno N Clinical significance of MUC-1 and E-cadherin expression, cellular proliferation, and angiogenesis at the deepest invasive portion of colorectal cancer. Int J Oncol 2000; $16: 55$

16. Liotta LA, Steeg PS, Stetler-Stevenson WG. Cancer metastasis and angiogenesis: an imbalance of positive and negative regulation. Cell 1991;64:327.

17. Lyndmark G, Gerdin B, Sundberg C, Pahlman L, Bergstrom R, Glimelius B Prognostic significance of the microvascular count in colorectal cancer. J Clin Oncol 1996; 14:461.

18. Macchiarini P, Fontanini G, Hardin MJ, Squartini F, Angeletti CA. Relation of neovascularisation to metastasis of non-small-cell lung cancer. Lancet 1992;340:145

19. Pavlopoulos PM, Konstantinidou AE, Agapitos E, Kavantzas N, Nikolopoulos $\mathrm{P}$, Davaris P. A morphometric study of neovascularization in colorectal carcinoma. Cancer 1998;83:2067.

20. Saclarides T, Speziale N, Elizabeth D, Szeluga DJ, Rubin DB. Tumor angiogenesis and rectal carcinoma. Dis Colon Rectum 1994;37:921.

21. Sneige N, Singletary E, Sahin A, El-Nagger A. Multiparameter analysis of potential prognostic factors in node negative breast cancer patients. Mod Pathol 1992;5:18.

22. Sternfeld T, Foss HD, Kruschewski M, Runkei N. The prognostic significance of tumor vascularization in patients with localized colorectal cancer. Int J Colorectal Dis 1999; $4: 272$

23. Takebayashi Y, Akiyama S-I, Yamada K, Akiba S, Aikou T. Angiogenesis as an unfavorable prognostic factor in human colorectal carcinoma. Cancer 1996; 78:226.

24. Takebayashi Y, Akiyama S, Yamada K, Akiba S, Miyadera K, Sumizawa T, Yamada Y, Murata F, Aikou T. Clinicopathological and prognostic significance of angiogenic factor, thymidine phosphorylase, in human colorectal carcinoma. J Natl Cancer Inst 1996;88:1110.

25. Takahashi Y, Tucker SL, Kitadai Y, Koura AN, Bucana CD, Cleary KR, Ellis LM Vessel counts and expression of vascular endothelial growth factor as prognostic factors in node-negative colon cancer. Arch Surg 1997;132:541.

26. Tanigawa N, Amaya H, Matsumara M, Lu C, Kitaoka A, Matsuyama K, Muraoka $\mathrm{R}$ Tumor angiogenesis and mode of metastasis in patients with colorectal cancer. Cancer Res 1997;57:1043. 
Tarta C, Teixeira CR, Tanaka S, Haruma K, Chiele-Neto C, Silva VD. Angiogenesis in advanced colorectal adenocarcinoma with special reference to tumoral invasion

27. Teixeira CR, Tanaka S, Haruma K, Yoshihara M, Sumii K, Kajiyama G, Shimamoto F. The clinical significance of the histologic subclassification of colorectal carcinoma. Oncology 1993;50:495.

28. Teixeira CR, Tanaka S, Haruma K, Yoshihara M, Sumii K, Kajiyama G. Proliferating cell nuclear antigen expression at the invasive tumor margin predicts malignant potential of colorectal carcinomas. Cancer 1994;73:575.

29. Tomisaki S-I, Ohno S, Ichiyoshi Y, Kuwano H, Maehara Y, Sugimachi K. Microvessel quantification and its possible relation with liver metastasis in colorectal cancer. Cancer 1996; 77 Suppl:1722.

30. Vermeulen PB, Gasparini G, Fox SB, Toi M, Martin L, Mcculloch P, Pezzella F, Viale G, Weidner N, Harris AL, Dirix LY. Quantification of angiogenesis in solid human tumours: an international consensus on the methodology and criteria of evaluation. Eur J Cancer 1996;32:2472.

31. Vermeulen PB, Van den Eynden GG, Huget P, Goovaerts G, Weyler J, Lardon F, Van Marck E, Hubens G, Dirix LY. Prospective study of intratumoral microvessel density, p53 expression and survival in colorectal cancer. Br J Cancer 1999;79:316

32. Weidner N, Semple JP, Welch WR, Folkman J. Tumor angiogenesis and metastasis - correlation in invasive breast carcinoma. N Engl J Med 1991;324:1.

33. Weidner N, Folkman J, Pozza F, Bevilacqua P, Allred EN, Moore DH, Meli S Gasparini G. Tumor angiogenesis: a new significant and independent prognostic indicator in early-stage breast carcinoma. J Natl Cancer Inst 1992;84:1875.

34. Weidner N. Intratumoral vascularity as a prognostic factor in cancers of the urogenital tract. Eur J Cancer 1996;32A:2506.

35. Yamazaki K, Abe S, Takekawa H, Sukoh N, Watanabe N, Ogura S, Nakajima I, Isobe H, Inoue K Kawakami Y. Tumor angiogenesis in human lung adenocarcinoma. Cancer 1994;74:2245. 